\title{
UK Renal Registry 16th Annual Report: Chapter 4 Demography of Patients Wait- listed for Renal Transplantation in the UK: National and Centre-specific Analyses
}

\author{
Rishi Pruthi ${ }^{a}$, Rachel Hilton ${ }^{b}$, Laura Pankhurst ${ }^{c}$, Nizam Mamode $^{b}$, Alex Hudson $^{c}$, \\ Paul Roderick ${ }^{\mathrm{d}}$, Rommel Ravanan ${ }^{\mathrm{e}}$ \\ aUK Renal Registry, Bristol, UK; ${ }^{\mathrm{b}}$ Guys \& St Thomas' Hospital, London, UK; ' $O r g a n$ Donation and Transplantation Directorate,

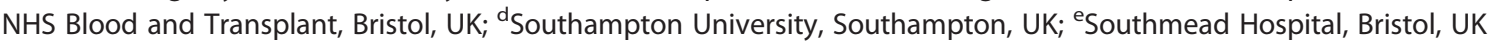

\section{Key Words}

Blood group · Calculated reaction frequency · Demography · End stage renal disease $\cdot$ Established renal failure $\cdot$ Ethnicity . Kidney allocation - Match grade $\cdot$ Prevalence $\cdot$ Renal replacement therapy - Transplantation - Transplant waiting list - Wait listing times

\begin{abstract}
Introduction: For suitable patients, renal transplantation is considered the optimal modality of renal replacement therapy, with availability of donor organs limiting the number of transplants undertaken. The 2006 kidney allocation policy was developed to ensure equity of allocation to patients on the transplant waiting list, whilst still achieving a good donor/recipient match. This study aims to describe the characteristics of the kidney transplant waiting list and variations in median waiting times. Methods: Demographics and clinical characteristics of all patients listed for a kidney only transplant in the UK on 1st January 2011 were examined. Renal unit variations were explored. Patients
\end{abstract}

listed between January 2006 and December 2009 were included in analysis of waiting times to transplant. Results: At the beginning of 2011, there were 6,699 patients registered active for kidney only transplant in UK; a prevalence rate of $107 \mathrm{pmp}$. The median age of prevalent listed patients was 53 years, with $8 \%$ aged 70 or above. Of the patients listed, $84 \%$ had started renal replacement therapy (RRT), $59 \%$ were male, $28 \%$ were from ethnic minorities, $50 \%$ had blood group type $0,28 \%$ were defined as difficult to HLA match and 23\% were highly sensitised (calculated HLA antibody reaction frequency $85 \%$ ). Median waiting time to transplant was 38 months. Waiting time was shorter for White patients (36 months) compared to Asian or Black patients (46 months), and was doubled in highly sensitised compared to un-sensitised patients. Conclusions: Intercentre variation was observed in the rate of wait-listing and in the proportion of listed patients across different ethnic groups, age, blood groups and level of sensitisation. This may reflect differences in baseline population characteristics as well as individual centre practice patterns. Median waiting times differ significantly across blood groups, degree of sensitisation and ethnic group.

$\begin{array}{ll}\text { KARGER } & \text { C } 2014 \mathrm{~S} . \text { Karger AG, Basel } \\ \text { Fax +4161306 1234 } & 1160-2110 / 14 / 1254-0081 \$ 38.00 / 0 \\ \begin{array}{l}\text { E-Mail karger@karger.com } \\ \text { www.karger.com }\end{array} & \begin{array}{l}\text { Accessible online at: } \\ \text { www.karger.com/nec }\end{array}\end{array}$

Rishi Pruthi

UK Renal Registry, Southmead Hospital, Southmead Road, Bristol, BS10 5NB, UK

Email: renalregistry@renalregistry.nhs.uk 


\section{Introduction}

For suitable patients with established renal failure (ERF), renal transplantation is accepted as the optimal modality of renal replacement therapy, conferring both better quality of life and better life expectancy than dialysis. In the UK, after completing necessary medical and surgical assessment (guided by national guidelines [1]), 'suitable' patients are listed for transplantation on the UK Transplant Registry at NHSBT (National Health Service Blood and Transplant). The number of people registered on this database however are far greater than the number of donor organs available in the UK which has led to the development and implementation of an allocation policy for deceased donor kidneys. This policy aims to ensure equity of allocation whilst taking into account the importance of achieving a good match between donor and recipient.

\section{Allocation policy}

All kidneys from deceased donors whose death has been defined by brain-stem death criteria are allocated through the national allocation scheme managed by NHSBT. The current scheme was implemented in 2006 to meet agreed objectives and address issues of inequity of access to transplantation and utilises an evidencebased computer algorithm $[2,3]$. This is based on a tier system, with all patients listed for kidney transplantation being allocated into one of five tiers (figure 4.1). Paediatric patients are prioritised within Tiers A and B according to waiting time, whilst within tiers $\mathrm{C}, \mathrm{D}$ and $\mathrm{E}$ patients are prioritised according to a points based system (highest score first), based on seven elements.
These are: waiting time, HLA match and age combined, donor-recipient age difference, geographical location of patient relative to donor, HLA-DR homozygosity, HLA-B homozygosity and blood group match (figure 4.1). Full details of the allocation policy can be accessed at: http://www.odt.nhs.uk/pdf/kidney_allocation_policy.pdf.

Whilst the analysis of these variables at a centre level is beyond the scope of a UK Renal Registry (UKRR) report, this report aims to provide clinicians with a better understanding of the 'make-up' of the UK Transplant Registry by:

(i) Defining the prevalence rates of listing, for individual UK countries and by age group

(ii) Providing centre level analysis of listing patterns by age group, ethnicity, gender, calculated HLA antibody reaction frequency (cRF), matchability score, blood group and primary renal disease (PRD)

(iii) Providing median waiting times by ethnicity, blood group and calculated HLA antibody reaction frequency $(\mathrm{cRF})$.

Clinicians may find these analyses provide a better understanding of their practice patterns and service needs.

\section{Methods}

These analyses relate to the prevalent patients active on the transplant waiting list in the UK at the beginning of 2011. The cohort was defined as all patients listed for renal transplantation

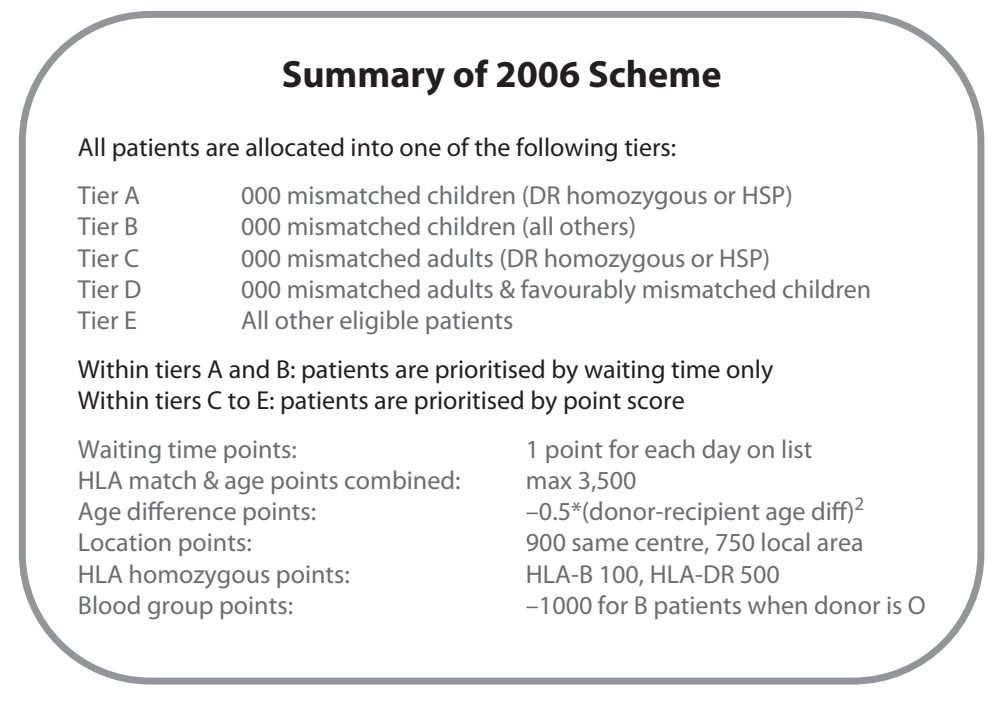

82
Nephron Clin Pract 2013;125:81-98
Fig. 4.1. Summary of national allocation scheme 
Table 4.1. Prevalence of registration for kidney transplantation and dialysis in the UK on $01 / 01 / 2011$ (including children $<18$ years)

\begin{tabular}{lcccc}
\hline & England & N Ireland & Scotland & Wales \\
\hline Total estimated population, mid-2010 (millions) & 52.2 & 1.8 & 5.2 & 3.0 \\
Total number registered for transplantation & 5,748 & 178 & 533 & 240 \\
Prevalence rate registration for transplantation (pmp) & 110 & 98 & 102 & 6,699 \\
Prevalence rate dialysis (pmp) & 424 & 440 & 415 & 49 \\
\hline
\end{tabular}

${ }^{*}$ Data from the Office for National Statistics, National Records of Scotland and the Northern Ireland Statistics and Research Agency $\mathrm{pmp}=$ per million population

on the UK Transplant Registry at NHSBT on 1st January 2011. Prevalent listed patients were extracted from the NHSBT database. Patients that had commenced dialysis were matched to the UKRR database. Patients were allocated to renal centres based on the origin of their data returns to the UKRR as opposed to their postcode. Population estimates were obtained from the UK Office of National Statistics (ONS) [4], the National Records of Scotland (NRS) [5] and the Northern Ireland Statistic and Research Agency (NISRA) [6]. Crude prevalence rates were calculated per million population ( $\mathrm{pmp}$ ) and centre level analyses were performed following a merge of data between NHSBT and the UKRR allowing listed patients to be re-allocated to their main renal centre.

The prevalence rate per million population for each centre was calculated using a derived catchment population. For a full description of the methodology used to estimate the catchment populations see appendix E: Methodology for Estimating Catchment Populations (www.renalreg.com). For Scotland, mid-2010 populations of Health Boards (HBs) (from the General Register Office for Scotland) were converted to centre level populations using an approximate mapping of renal centres to HBs supplied by the Scottish Renal Registry. Estimates of the catchment populations in Northern Ireland were supplied by personal communication from Dr D Fogarty.

Throughout this chapter, haemodialysis refers to all modes of HD treatment, including haemodiafiltration (HDF). Several centres reported significant numbers of patients on HDF, but other centres did not differentiate this treatment type in their UKRR returns. Prevalent patients listed for transplantation were examined by gender, ethnicity, age group, primary renal disease, blood group, match grade and calculated HLA antibody reaction frequency (Report appendix H: Coding (www.renalreg.com). Analyses were done for the UK as a whole, by UK country, at centre level and split by treatment modality as appropriate.

Match grade was calculated for each listed patient by NHSBT using a pool of 10,000 donors that were blood group identical, HLA compatible and 000 or favourably $(100,010,110)$ HLA mismatched. The match count was then converted into a standardised score, and categorised as: easy to match (1-3), moderate to match (4-7) and difficult to match (8-10). UK and centre analyses were performed using the three generated categories.

Calculated HLA antibody reaction frequency (cRF) for each patient was determined by NHS Blood \& Transplant-Organ Donation and Transplantation Directorate (NHSBT-ODT) from the unacceptable HLA specificities reported for each patient. The unacceptable specificities were compared with the HLA types of blood group identical donors from a pool of 10,000 UK donors and the resulting HLA antibody reaction frequency (cRF) was expressed as a percentage of HLA incompatible donors. These were then categorised into five groups: '0-9\%', '10-29\%', '30$84 \%$ ', and ' $85 \%$ '; '0-9\%' was classed as being un-sensitised, and ' $85 \%$ ' was classed as being highly sensitised.

Chi-squared test, Fisher's exact test and Kruskal Wallis tests were used as appropriate to test for significant differences between groups. The data were analysed using SAS 9.3.

\section{Results}

\section{Prevalent patient numbers listed for transplantation}

There were 6,699 patients registered on the active transplant list for kidney only transplantation at the beginning of 2011, giving a UK population prevalence rate for listing for kidney transplantation of $107 \mathrm{pmp}$ compared with a dialysis prevalence rate of $424 \mathrm{pmp}$ (table 4.1). There were no significant differences in prevalence rates for dialysis in all four of the UK countries; however prevalence rates for listing were significantly lower in Wales at $79 \mathrm{pmp}$. This may be explained by the higher prevalence rate of dialysis for patients aged $>80$ seen in Wales who are less likely to be listed. Figure 4.2 shows that Northern Ireland had a higher prevalence rate for listing patients aged $65+$ compared with the other UK countries, mirroring the trend seen in prevalence of dialysis patients in $U K$ countries (chapter 2).

\section{Prevalent patients listed for transplantation by RRT modality and centre}

The number of prevalent patients listed for transplantation in each renal centre and the distribution of their treatment modalities varied widely (table 4.2). Many factors including geography, local population density, age distribution, ethnic composition, prevalence of diseases predisposing to kidney disease and the social deprivation index of that population may contribute to 
Table 4.2. Number of prevalent listed patients by treatment modality and centre on 01/01/2011

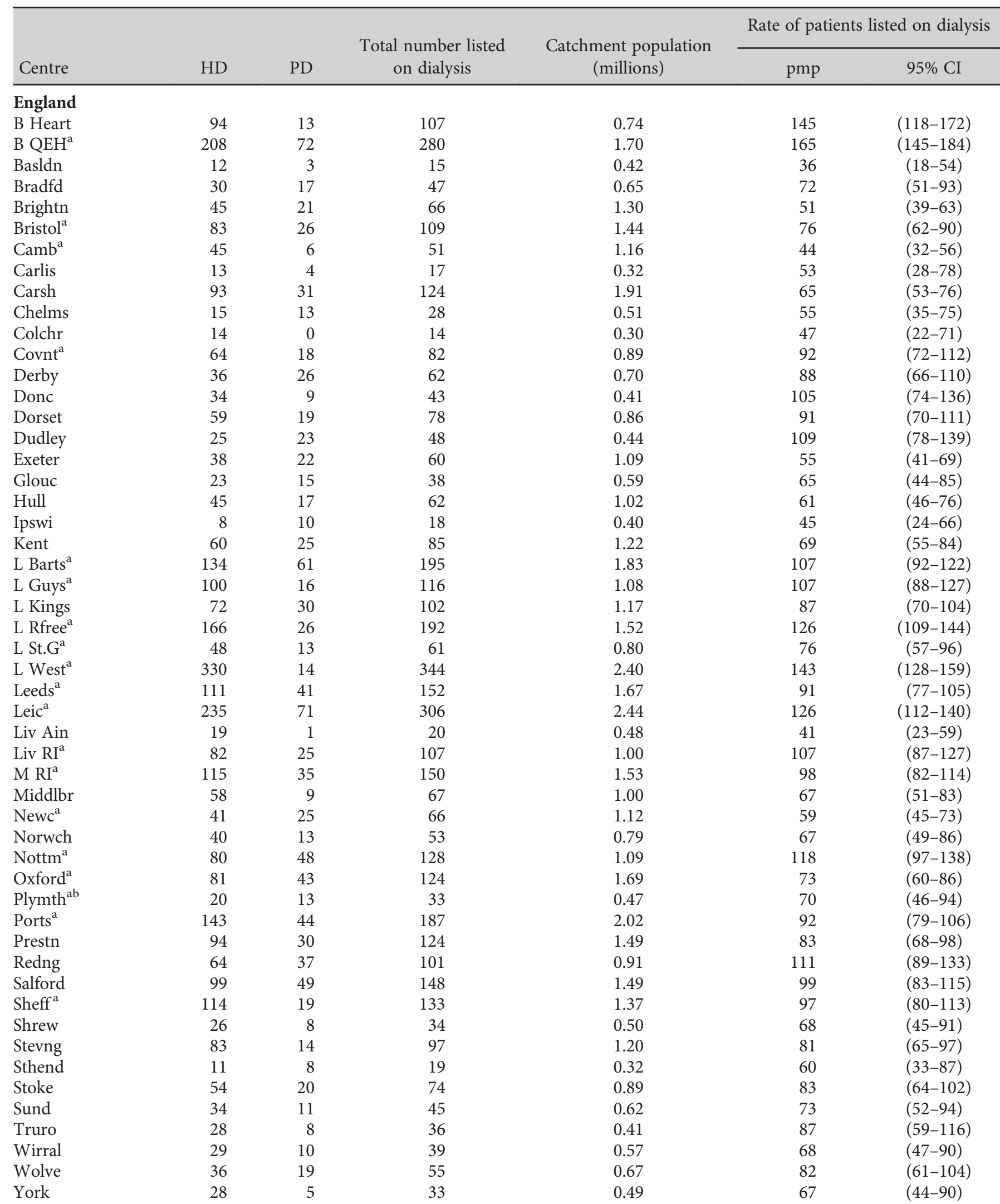


Table 4.2. Continued

\begin{tabular}{|c|c|c|c|c|c|c|}
\hline \multirow[b]{2}{*}{ Centre } & \multirow[b]{2}{*}{ HD } & \multirow[b]{2}{*}{$\mathrm{PD}$} & \multirow{2}{*}{$\begin{array}{c}\text { Total number listed } \\
\text { on dialysis }\end{array}$} & \multirow{2}{*}{$\begin{array}{l}\text { Catchment population } \\
\text { (millions) }\end{array}$} & \multicolumn{2}{|c|}{ Rate of patients listed on dialysis } \\
\hline & & & & & $\mathrm{pmp}$ & $95 \% \mathrm{CI}$ \\
\hline \multicolumn{7}{|c|}{ Northern Ireland } \\
\hline Antrim & 11 & 3 & 14 & 0.30 & 47 & $(22-71)$ \\
\hline Belfast $^{\mathrm{a}}$ & 50 & 12 & 62 & 0.55 & 113 & $(85-141)$ \\
\hline Newry & 20 & 3 & 23 & 0.28 & 82 & $(49-116)$ \\
\hline \multicolumn{7}{|l|}{ Scotland } \\
\hline Abrdn & 37 & 11 & 48 & 0.60 & 80 & $(57-103)$ \\
\hline Airdrie & 27 & 3 & 30 & 0.56 & 54 & $(34-73)$ \\
\hline D \& Gall & 10 & 2 & 12 & 0.15 & 80 & $(35-125)$ \\
\hline Dundee & 16 & 7 & 23 & 0.41 & 56 & $(33-79)$ \\
\hline Dunfn & 19 & 7 & 26 & 0.37 & 70 & $(43-97)$ \\
\hline \multicolumn{7}{|l|}{ Wales } \\
\hline Bangor & 14 & 4 & 18 & 0.22 & 83 & $(44-121)$ \\
\hline Cardff $^{\mathrm{a}}$ & 64 & 29 & 93 & 1.42 & 65 & $(52-79)$ \\
\hline Clwyd & 11 & 2 & 13 & 0.19 & 69 & $(31-106)$ \\
\hline Swanse & 45 & 12 & 57 & 0.89 & 64 & $(48-81)$ \\
\hline Wrexm & 8 & 6 & 14 & 0.24 & 58 & $(28-89)$ \\
\hline England & 3,619 & 1,156 & 4,775 & & & \\
\hline N Ireland & 128 & 23 & 151 & & & \\
\hline Scotland & 402 & 94 & 496 & & & \\
\hline Wales & 142 & 53 & 195 & & & \\
\hline UK & 4,291 & 1,326 & 5,617 & & & \\
\hline
\end{tabular}

Centres prefixed 'L' are London centres

The numbers of patients calculated for each country quoted above differ marginally from those quoted elsewhere when patients are allocated to areas by their individual postcodes, as some centres treat patients from across national boundaries

${ }^{a}$ Transplant centres

${ }^{\mathrm{b}}$ The catchment population for Plymouth may be too low, see appendix E

this. Many of these factors are also likely to be the cause behind the wide inter-centre variation seen in listing patients pre-emptively between transplant centres with a range of 11 to 125 patients listed across 24 transplanting centres (table 4.3).

\section{Case mix in prevalent wait-listed patients} Gender

Table 4.4 shows that the gender distribution of patients listed for transplantation was similar to that seen in the prevalent dialysis population with $59 \%$ of patients listed

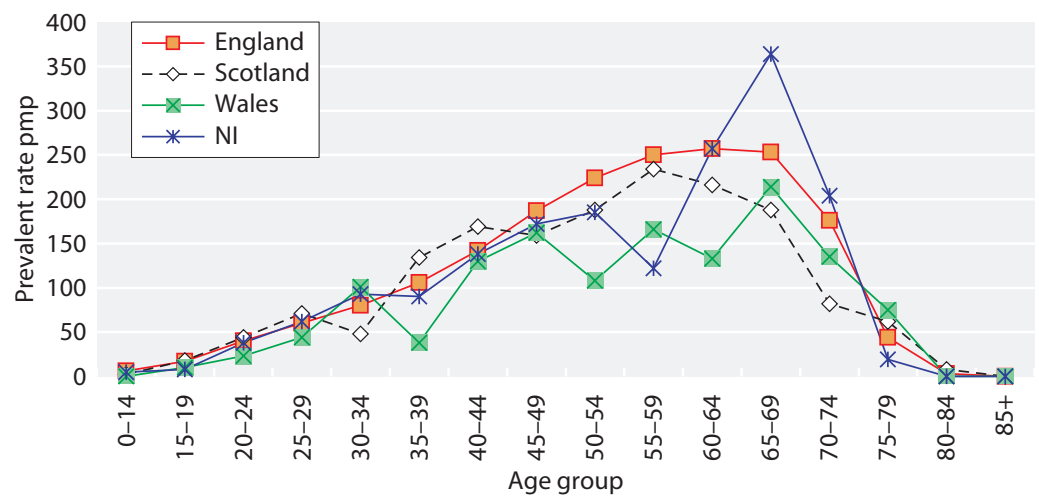

Fig. 4.2. Prevalence rates of registration for kidney transplantation in the UK per million population by age group and UK country on $01 / 01 / 2011$ 
Table 4.3. Number of prevalent listed patients pre-emptively listed by transplant centre on $01 / 01 / 2011$

\begin{tabular}{lc}
\hline Transplant centre & Number of pre-emptive listed patients \\
\hline M RI & 125 \\
B QEH & 112 \\
Leic & 97 \\
L Guys & 71 \\
Bristol & 67 \\
L Rfree & 61 \\
L St.G & 56 \\
L West & 56 \\
Leeds & 50 \\
Oxford & 49 \\
Camb & 34 \\
Liv RI & 33 \\
Nottm & 31 \\
Newc & 30 \\
Sheff & 30 \\
Ports & 30 \\
Cardiff & 29 \\
Belfast & 27 \\
Glasgw & 19 \\
L Barts & 18 \\
Edin & 16 \\
Plymth & 15 \\
L GOSH & 15 \\
Covnt & 11 \\
UK & $\mathbf{1 , 0 8 2}$ \\
\hline
\end{tabular}

being male. There was wide inter-centre variation with a range of $37-91 \%$, and only 11 centres had a preponderance of women listed (figure 4.3). Sub-analysis by modality did not show any significant gender differences.

\section{Ethnicity}

Ethnicity completeness for prevalent listed patients in the UK was $100 \%$ at the beginning of 2011 across all UK countries. Table 4.4 shows that a quarter of the patients listed $(25 \%)$ were from ethnic minority groups (Black or South Asian) which compared to $12 \%$ of the UK general population who were designated as belonging to an ethnic minority. Whilst there was little difference across modalities, Black patients were seen to have the lowest proportion of pre-emptively listed patients, with only $10 \%(61 / 593)$ of listed Black patients being preemptively listed compared to $17 \%(817 / 4,835)$ and $16 \%$ $(175 / 1,089)$ of White and South Asian listed patients respectively. Amongst renal centres there was wide variation between centres with respect to the proportion of patients listed from ethnic minorities (table 4.5, figure 4.4), ranging from zero percent ( $0 \%$ ) in 12 centres to over $50 \%$ in London Barts (72\%), London West (70\%), London St Georges (69\%), London Kings (69\%), London Royal Free (65\%), Birmingham Heartlands (61\%) and London Guys (53\%).

\section{Age}

The median age of prevalent listed patients on dialysis at 1st January 2011 was 53 years, which was significantly lower than the median age of the prevalent HD patients (66.3 years) and those on PD (61.7 years), $p<0.0001$. As for those listed pre-emptively the median age was slightly lower than those on dialysis at 52 years. Table 4.4 shows that $79 \%$ of the UK prevalent listed

Table 4.4. Number and percentage of prevalent listed patients and their modalities by gender, ethnicity and age group on $01 / 01 / 2011$

\begin{tabular}{|c|c|c|c|c|c|c|c|c|c|}
\hline & & \multicolumn{6}{|c|}{ Modality } & & \\
\hline & & \multicolumn{2}{|c|}{$\mathrm{HD}$} & \multicolumn{2}{|c|}{$\mathrm{PD}$} & \multicolumn{2}{|c|}{ Pre-emptive } & \multicolumn{2}{|c|}{ Total } \\
\hline & & $N$ & $\%$ & $N$ & $\%$ & $N$ & $\%$ & $N$ & $\%$ \\
\hline Gender & Male & 2,595 & 60 & 724 & 55 & 614 & 57 & 3,933 & 59 \\
\hline & Asian & 738 & 17 & 176 & 13 & 175 & 16 & 1,089 & 16 \\
\hline & Black & 461 & 11 & 71 & 5 & 61 & 6 & 593 & 9 \\
\hline & Other & 124 & 3 & 29 & 2 & 29 & 3 & 182 & 3 \\
\hline Age group & $0-17$ & 20 & 0 & 24 & 2 & 52 & 5 & 96 & 1 \\
\hline
\end{tabular}




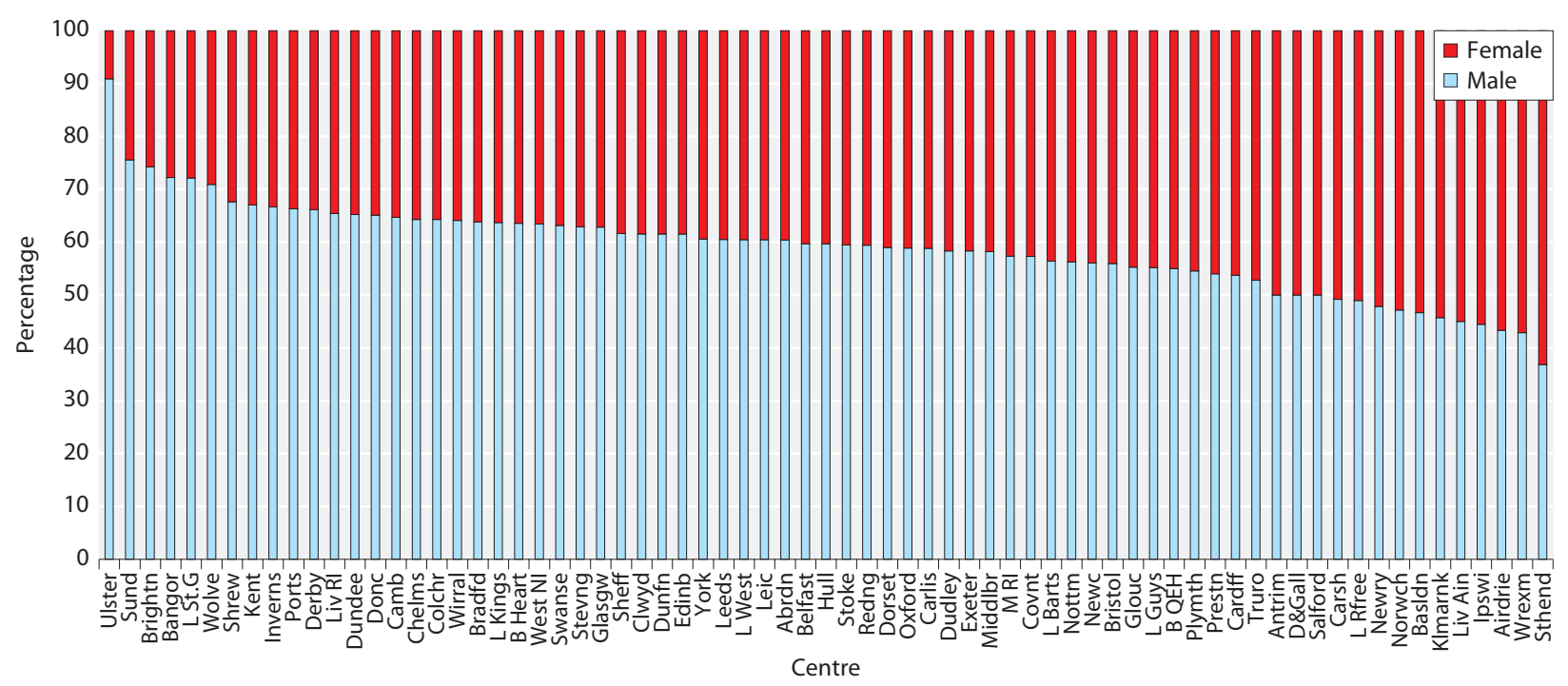

Fig. 4.3. Percentage of prevalent listed patients by gender and centre on $01 / 01 / 2011$

Table 4.5. Ethnicity of prevalent listed patients by centre on $01 / 01 / 2011$

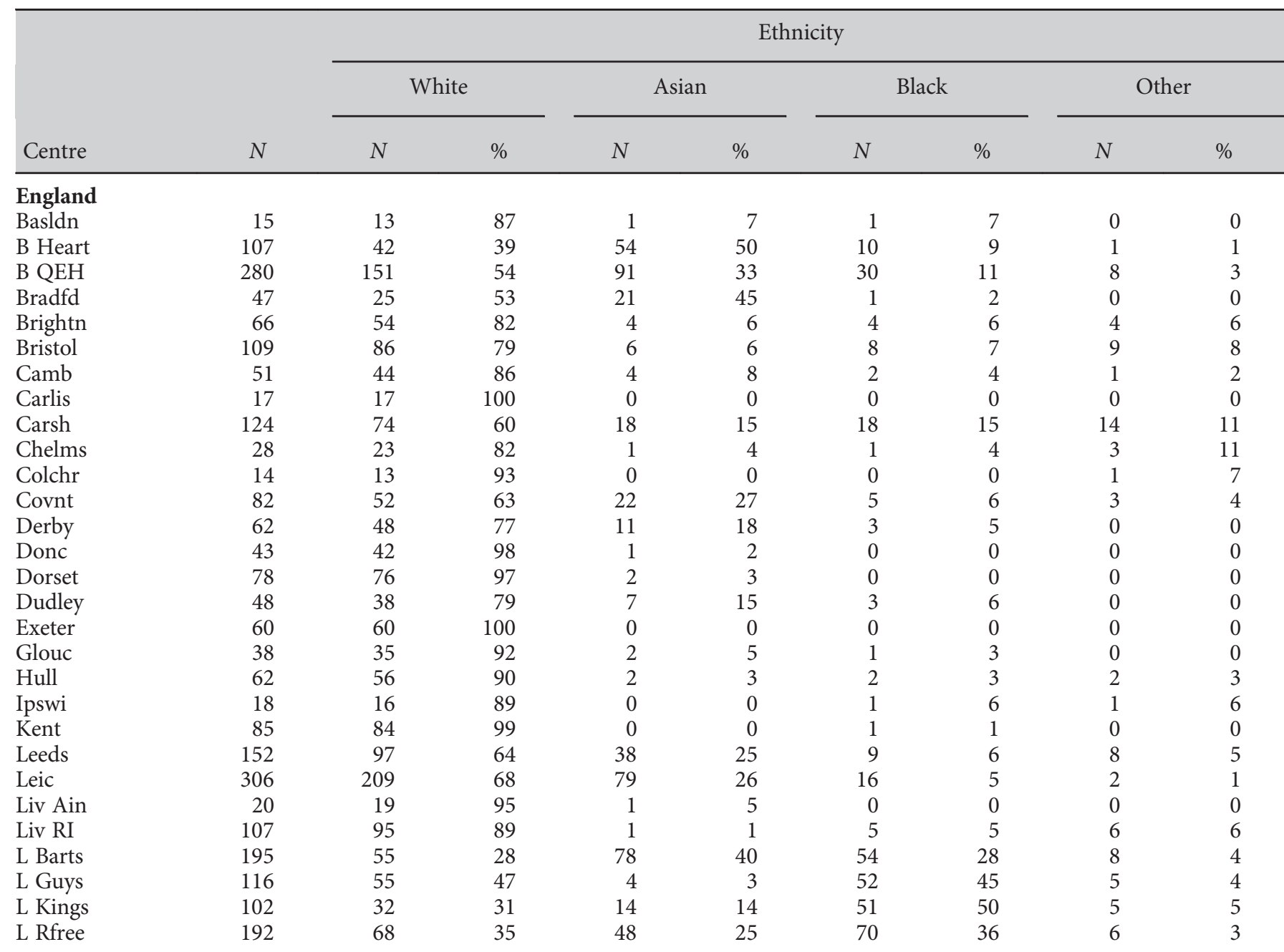


Table 4.5. Continued

\begin{tabular}{|c|c|c|c|c|c|c|c|c|c|}
\hline \multirow[b]{3}{*}{ Centre } & \multirow[b]{3}{*}{$N$} & \multicolumn{8}{|c|}{ Ethnicity } \\
\hline & & \multicolumn{2}{|c|}{ White } & \multicolumn{2}{|c|}{ Asian } & \multicolumn{2}{|c|}{ Black } & \multicolumn{2}{|c|}{ Other } \\
\hline & & $N$ & $\%$ & $N$ & $\%$ & $N$ & $\%$ & $N$ & $\%$ \\
\hline L St.G & 61 & 19 & 31 & 18 & 30 & 18 & 30 & 6 & 10 \\
\hline L West & 344 & 104 & 30 & 143 & 42 & 77 & 22 & 20 & 6 \\
\hline M RI & 150 & 103 & 69 & 33 & 22 & 11 & 7 & 3 & 2 \\
\hline Middlbr & 67 & 64 & 96 & 2 & 3 & 1 & 1 & 0 & 0 \\
\hline Newc & 66 & 61 & 92 & 4 & 6 & 0 & 0 & 1 & 2 \\
\hline Norwch & 53 & 50 & 94 & 2 & 4 & 0 & 0 & 1 & 2 \\
\hline Nottm & 128 & 106 & 83 & 7 & 5 & 12 & 9 & 3 & 2 \\
\hline Oxford & 124 & 89 & 72 & 21 & 17 & 10 & 8 & 4 & 3 \\
\hline Plymth & 33 & 32 & 97 & 0 & 0 & 0 & 0 & 1 & 3 \\
\hline Ports & 187 & 161 & 86 & 10 & 5 & 10 & 5 & 6 & 3 \\
\hline Prestn & 124 & 100 & 81 & 21 & 17 & 2 & 2 & 1 & 1 \\
\hline Redng & 101 & 60 & 59 & 32 & 32 & 8 & 8 & 1 & 1 \\
\hline Salford & 148 & 111 & 75 & 31 & 21 & 4 & 3 & 2 & 1 \\
\hline Sheff & 133 & 119 & 89 & 8 & 6 & 5 & 4 & 1 & 1 \\
\hline Shrew & 34 & 31 & 91 & 1 & 3 & 2 & 6 & 0 & 0 \\
\hline Sthend & 19 & 15 & 79 & 1 & 5 & 2 & 11 & 1 & 5 \\
\hline Stevng & 97 & 69 & 71 & 16 & 16 & 10 & 10 & 2 & 2 \\
\hline Stoke & 74 & 65 & 88 & 6 & 8 & 2 & 3 & 1 & 1 \\
\hline Sund & 45 & 43 & 96 & 1 & 2 & 0 & 0 & 1 & 2 \\
\hline Truro & 36 & 35 & 97 & 0 & 0 & 0 & 0 & 1 & 3 \\
\hline Wirral & 39 & 33 & 85 & 3 & 8 & 1 & 3 & 2 & 5 \\
\hline Wolve & 55 & 37 & 67 & 16 & 29 & 2 & 4 & 0 & 0 \\
\hline York & 33 & 32 & 97 & 0 & 0 & 0 & 0 & 1 & 3 \\
\hline \multicolumn{10}{|l|}{ N Ireland } \\
\hline Antrim & 14 & 14 & 100 & 0 & 0 & 0 & 0 & 0 & 0 \\
\hline Belfast & 62 & 60 & 97 & 1 & 2 & 0 & 0 & 1 & 2 \\
\hline Newry & 23 & 22 & 96 & 0 & 0 & 0 & 0 & 1 & 4 \\
\hline Ulster & 11 & 11 & 100 & 0 & 0 & 0 & 0 & 0 & 0 \\
\hline West NI & 41 & 41 & 100 & 0 & 0 & 0 & 0 & 0 & 0 \\
\hline \multicolumn{10}{|l|}{ Scotland } \\
\hline Abrdn & 48 & 45 & 94 & 2 & 4 & 1 & 2 & 0 & 0 \\
\hline Airdrie & 30 & 30 & 100 & 0 & 0 & 0 & 0 & 0 & 0 \\
\hline D \& Gall & 12 & 12 & 100 & 0 & 0 & 0 & 0 & 0 & 0 \\
\hline Dundee & 23 & 22 & 96 & 1 & 4 & 0 & 0 & 0 & 0 \\
\hline Dunfn & 26 & 26 & 100 & 0 & 0 & 0 & 0 & 0 & 0 \\
\hline Edinb & 91 & 88 & 97 & 2 & 2 & 0 & 0 & 1 & 1 \\
\hline Glasgw & 210 & 193 & 92 & 12 & 6 & 4 & 2 & 1 & 0 \\
\hline Inverns & 21 & 21 & 100 & 0 & 0 & 0 & 0 & 0 & 0 \\
\hline Klmarnk & 35 & 33 & 94 & 1 & 3 & 0 & 0 & 1 & 3 \\
\hline \multicolumn{10}{|l|}{ Wales } \\
\hline Bangor & 18 & 18 & 100 & 0 & 0 & 0 & 0 & 0 & 0 \\
\hline Cardff & 93 & 83 & 89 & 7 & 8 & 1 & 1 & 2 & 2 \\
\hline Clwyd & 13 & 13 & 100 & 0 & 0 & 0 & 0 & 0 & 0 \\
\hline Swanse & 57 & 54 & 95 & 2 & 4 & 1 & 2 & 0 & 0 \\
\hline Wrexm & 14 & 14 & 100 & 0 & 0 & 0 & 0 & 0 & 0 \\
\hline England & 4,775 & 3,218 & 67 & 886 & 19 & 525 & 11 & 146 & 3 \\
\hline Northern Ireland & 151 & 148 & 98 & 1 & 1 & 0 & $\mathbf{0}$ & 2 & 1 \\
\hline Scotland & 496 & 470 & 95 & 18 & 4 & 5 & 1 & 3 & 1 \\
\hline Wales & 195 & 182 & 93 & 9 & 5 & 2 & 1 & 2 & 1 \\
\hline UK & 5,617 & 4,018 & 72 & 914 & 16 & 532 & 9 & 153 & 3 \\
\hline
\end{tabular}




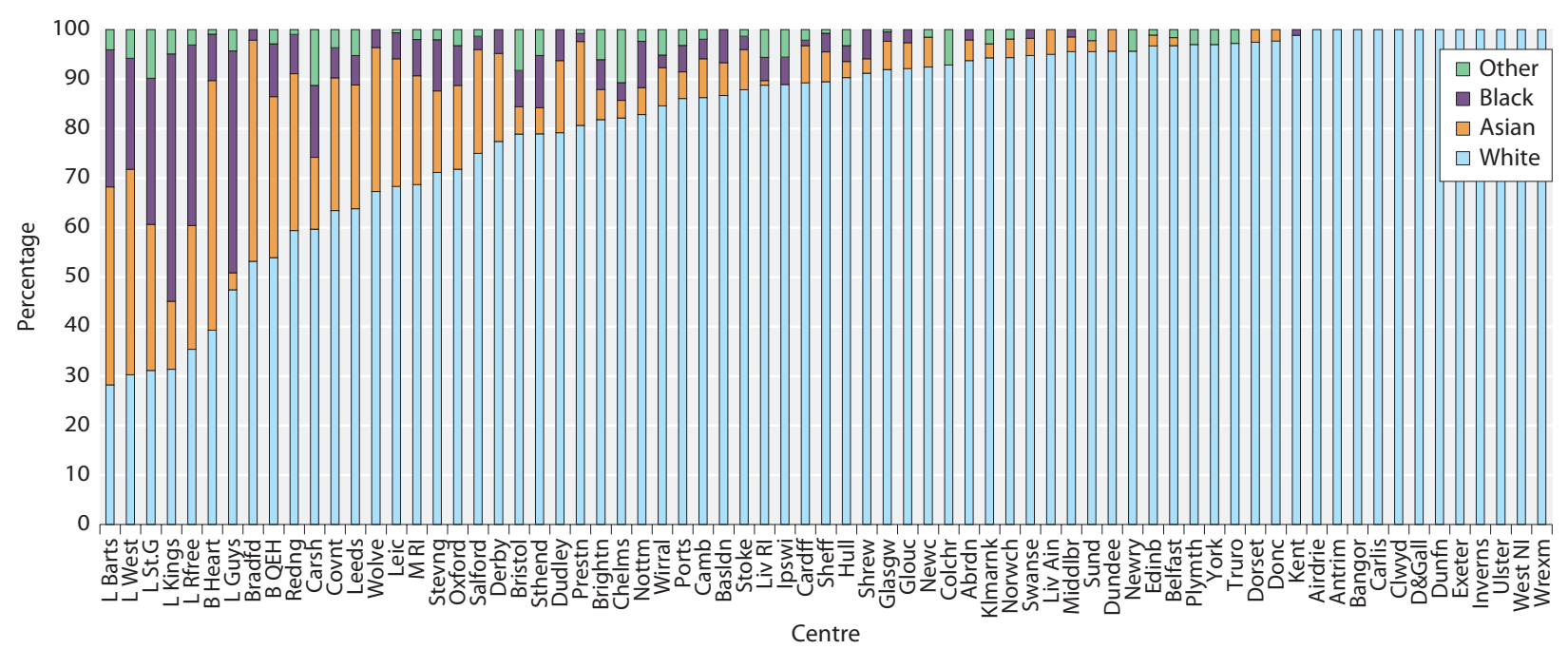

Fig. 4.4. Ethnicity of prevalent listed patients by centre on $01 / 01 / 2011$

population was aged between $35-69$ years, with only $8 \%$ of patients aged 70 or above. The proportion of patients listed aged 70 or more was $8 \%$ in England, $11 \%$ in Wales, $7 \%$ in Northern Ireland and 6\% in Scotland (table 4.6). Analysis by centre (table 4.6) showed wide variation in the proportion of patients listed aged 70 or above by centre with four centres (Basildon, Colchester, Ipswich and London Barts) listing no patients, compared

Table 4.6. Number and percentage of prevalent listed patients in each age group by centre on $01 / 01 / 2011$

\begin{tabular}{|c|c|c|c|c|c|c|c|c|c|c|c|c|}
\hline \multirow[b]{3}{*}{ Centre } & \multicolumn{12}{|c|}{ Age group (years) } \\
\hline & \multicolumn{2}{|c|}{$0-17$} & \multicolumn{2}{|c|}{$18-34$} & \multicolumn{2}{|c|}{$35-49$} & \multicolumn{2}{|c|}{$50-59$} & \multicolumn{2}{|c|}{$60-69$} & \multicolumn{2}{|c|}{$70+$} \\
\hline & $N$ & $\%$ & $N$ & $\%$ & $N$ & $\%$ & $N$ & $\%$ & $N$ & $\%$ & $N$ & $\%$ \\
\hline \multicolumn{13}{|l|}{ England } \\
\hline Basldn & & & 1 & 7 & 5 & 33 & 6 & 40 & 3 & 20 & & \\
\hline B Heart & & & 17 & 16 & 27 & 25 & 27 & 25 & 24 & 22 & 12 & 11 \\
\hline $\mathrm{B} \mathrm{QEH}$ & 4 & 1 & 38 & 14 & 73 & 26 & 90 & 32 & 60 & 21 & 15 & 5 \\
\hline Bradfd & & & 11 & 23 & 15 & 32 & 10 & 21 & 8 & 17 & 3 & 6 \\
\hline Brightn & 1 & 2 & 7 & 11 & 16 & 24 & 16 & 24 & 17 & 26 & 9 & 14 \\
\hline Bristol & 3 & 3 & 12 & 11 & 35 & 32 & 23 & 21 & 29 & 27 & 7 & 6 \\
\hline Camb & & & 5 & 10 & 17 & 33 & 16 & 31 & 8 & 16 & 5 & 10 \\
\hline Carlis & & & 2 & 12 & 5 & 29 & 4 & 24 & 5 & 29 & 1 & 6 \\
\hline Carsh & & & 12 & 10 & 37 & 30 & 28 & 23 & 37 & 30 & 10 & 8 \\
\hline Chelms & & & 3 & 11 & 8 & 29 & 9 & 32 & 7 & 25 & 1 & 4 \\
\hline Colchr & & & & & 3 & 21 & 2 & 14 & 9 & 64 & & \\
\hline Covnt & & & 6 & 7 & 24 & 29 & 27 & 33 & 19 & 23 & 6 & 7 \\
\hline Derby & & & 8 & 13 & 15 & 24 & 15 & 24 & 20 & 32 & 4 & 6 \\
\hline Donc & & & 6 & 14 & 10 & 23 & 10 & 23 & 13 & 30 & 4 & 9 \\
\hline Dorset & & & 7 & 9 & 17 & 22 & 12 & 15 & 26 & 33 & 16 & 21 \\
\hline Dudley & & & 5 & 10 & 15 & 31 & 15 & 31 & 11 & 23 & 2 & 4 \\
\hline Exeter & & & 4 & 7 & 16 & 27 & 15 & 25 & 22 & 37 & 3 & 5 \\
\hline Glouc & & & 5 & 13 & 10 & 26 & 9 & 24 & 9 & 24 & 5 & 13 \\
\hline Hull & & & 8 & 13 & 21 & 34 & 16 & 26 & 15 & 24 & 2 & 3 \\
\hline Ipswi & & & 4 & 22 & 8 & 44 & 5 & 28 & 1 & 6 & & \\
\hline Kent & & & 8 & 9 & 17 & 20 & 23 & 27 & 31 & 36 & 6 & 7 \\
\hline Leeds & 10 & 7 & 22 & 14 & 47 & 31 & 36 & 24 & 26 & 17 & 11 & 7 \\
\hline Leic & & & 31 & 10 & 71 & 23 & 67 & 22 & 95 & 31 & 42 & 14 \\
\hline Liv Ain & & & 4 & 20 & 5 & 25 & 4 & 20 & 4 & 20 & 3 & 15 \\
\hline Liv RI & & & 14 & 13 & 39 & 36 & 30 & 28 & 19 & 18 & 5 & 5 \\
\hline L Barts & & & 30 & 15 & 63 & 32 & 71 & 36 & 31 & 16 & & \\
\hline
\end{tabular}


Table 4.6. Continued

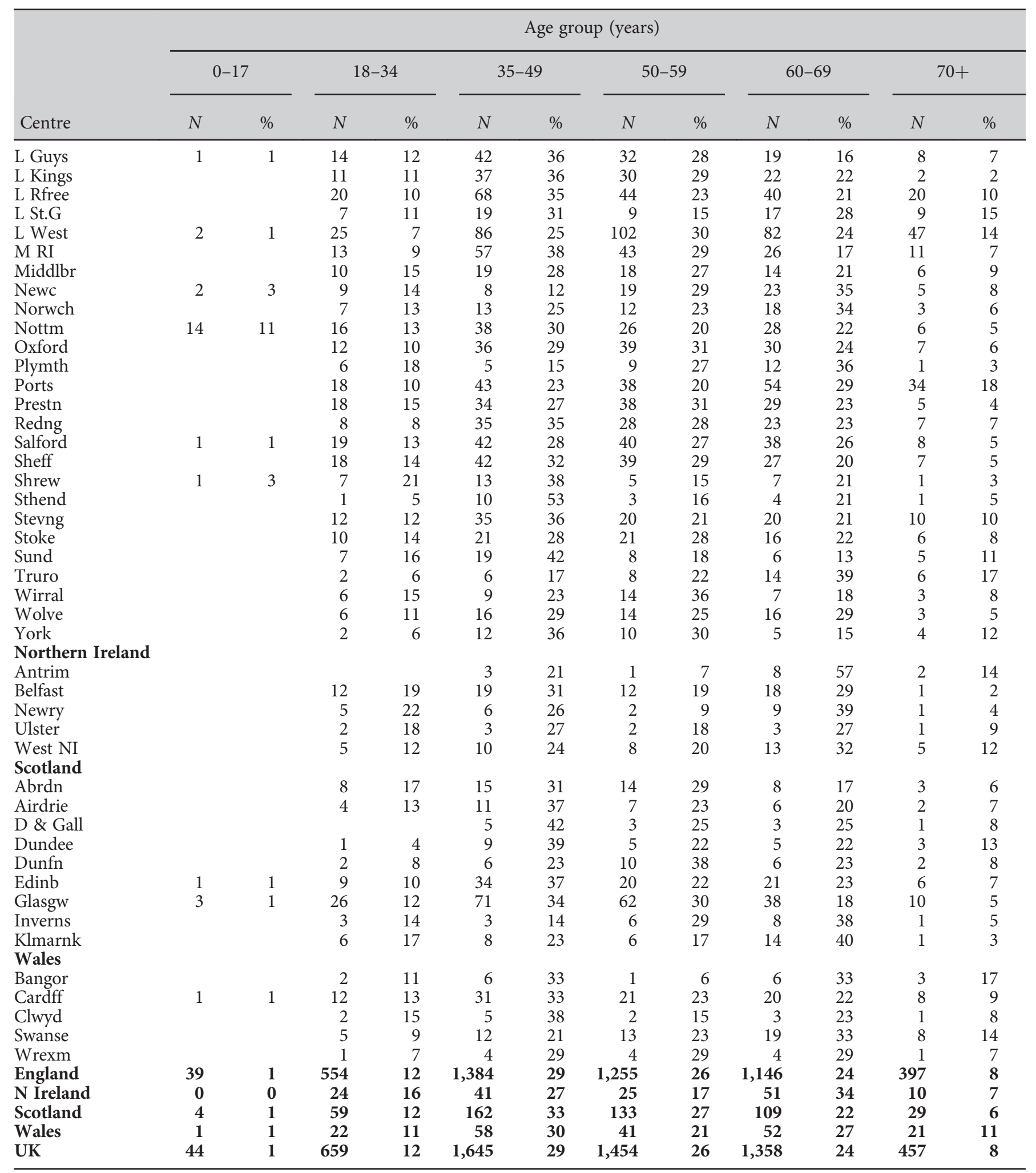

The numbers of patients calculated for each country quoted above differ marginally from those quoted elsewhere when patients are allocated to areas by their individual postcodes, as some centres treat patients from across national boundaries

Blank cells denote no patients listed for that age group within corresponding centre 


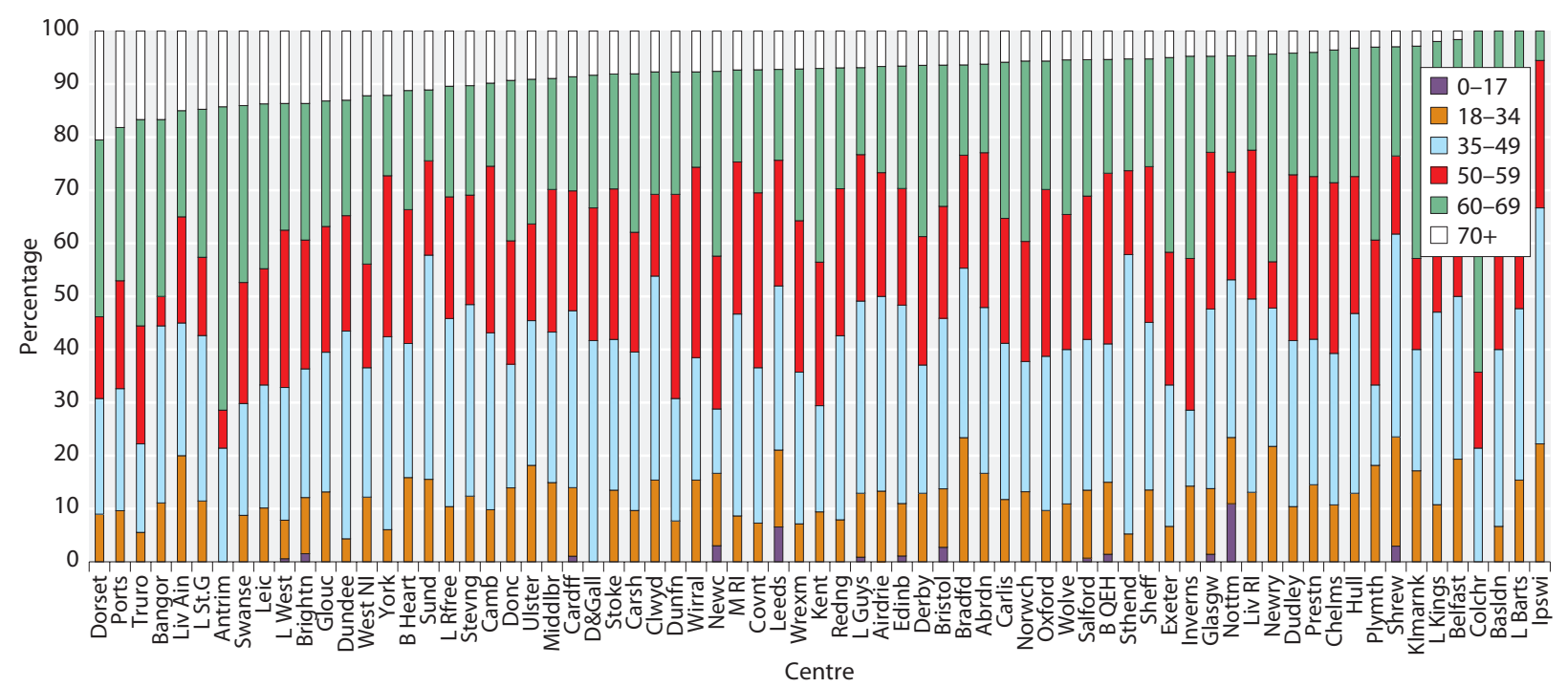

Fig. 4.5. Percentage of listed patients in each age group on $01 / 01 / 2011$ by centre

to Dorset, Portsmouth, Truro and Bangor, where more than a sixth of their listed patients were aged 70 or more (figure 4.5). These differences may be due to variation in local listing practices, although could also reflect variation in the ethnic make-up of the catchment population and the social deprivation index of the local population.

\section{Primary renal diagnosis}

Data for primary renal diagnosis (PRD) were not complete for $3 \%$ of patients (table 4.7) and there remained a marked inter-centre difference in completeness of data returns for PRD to the UKRR. Glomerulonephritis (GN) was the most common PRD amongst patients listed for transplantation on 1st January 2011 at $22 \%$ (table 4.7 ), whilst hypertension only accounted for $7 \%$ and renovascular disease only $2 \%$. This may be explained by the fact that younger patients (age $<65$ years) who are more likely to be listed are more likely to have GN or pyelonephritis and less likely to have renovascular disease or hypertension as the cause of their renal failure which are more prominent in older age.

Diabetes accounted for just $10 \%$ of listed patients, lower than the $15 \%$ seen in prevalent patients.

Amongst patients pre-emptively listed the most common diagnosis was polycystic kidney disease (PKD), which is probably a reflection of the fact that these patients are often known to renal services for many

Table 4.7. Number and percentage of prevalent listed patients and their modalities by primary renal diagnosis on $01 / 01 / 2011$

\begin{tabular}{|c|c|c|c|c|c|c|c|c|}
\hline \multirow[b]{3}{*}{ Primary renal diagnosis } & \multicolumn{6}{|c|}{ Modality } & & \\
\hline & \multicolumn{2}{|c|}{ HD } & \multicolumn{2}{|c|}{$\mathrm{PD}$} & \multicolumn{2}{|c|}{ Pre-emptive } & \multicolumn{2}{|c|}{ Total } \\
\hline & $N$ & $\%$ & $N$ & $\%$ & $N$ & $\%$ & $N$ & $\%$ \\
\hline Diabetes & 463 & 11 & 114 & 9 & 41 & 6 & 618 & 10 \\
\hline Glomerulonephritis & 926 & 22 & 323 & 24 & 124 & 20 & 1,373 & 22 \\
\hline Hypertension & 311 & 7 & 83 & 6 & 26 & 4 & 420 & 7 \\
\hline Missing & 127 & 3 & 40 & 3 & 47 & 7 & 214 & 3 \\
\hline Other & 709 & 17 & 212 & 16 & 84 & 13 & 1,005 & 16 \\
\hline Polycystic kidney disease & 493 & 11 & 189 & 14 & 131 & 21 & 813 & 13 \\
\hline Pyelonephritis & 489 & 11 & 126 & 10 & 72 & 11 & 687 & 11 \\
\hline Renovascular & 89 & 2 & 21 & 2 & 8 & 1 & 118 & 2 \\
\hline Uncertain & 684 & 16 & 218 & 16 & 103 & 16 & 1,005 & 16 \\
\hline
\end{tabular}


Table 4.8. Number and percentage of prevalent listed patients and their modalities by blood group, match grade and cRF group on $01 / 01 / 2011$

\begin{tabular}{|c|c|c|c|c|c|c|c|c|c|}
\hline & & & & & & & & & \\
\hline & & & & & & & & & \\
\hline & & $N$ & $\%$ & $N$ & $\%$ & $N$ & $\%$ & $N$ & $\%$ \\
\hline Blood group & $\mathrm{O}$ & 2,189 & 51 & 639 & 48 & 517 & 48 & 3,345 & 50 \\
\hline & A & 1,290 & 30 & 475 & 36 & 373 & 35 & 2,138 & 32 \\
\hline Match grade & Easy & 1,175 & 27 & 482 & 36 & 422 & 39 & 2,079 & 31 \\
\hline & Moderate & 1,684 & 39 & 601 & 45 & 492 & 46 & 2,777 & 41 \\
\hline & Difficult & 1,432 & 33 & 243 & 18 & 167 & 15 & 1,842 & 28 \\
\hline cRF group & 0 to $<10$ & 2,191 & 51 & 833 & 63 & 767 & 71 & 3,791 & 57 \\
\hline
\end{tabular}

years prior to starting dialysis allowing their timely work up to be pre-emptively listed.

\section{Blood group}

Table 4.8 shows that $50 \%$ of patients listed had blood group type $\mathrm{O}$, whilst blood group $\mathrm{AB}$ was the least common accounting for just $3 \%$ of listed patients. The percentage of patients listed with blood group B (who are known to have the longest median waiting times) showed inter-centre variation (see table 4.9, figure 4.6) with some centres having more than a quarter of patients listed with blood group B (London St George's 31\% and London West 26\%) whilst four centres had none (Antrim, Basildon, Colchester, Truro). This may partly be due to the ethnic make-up of the catchment population with both London West and St George's having a large non-White prevalent dialysis population. Additionally the actual number of patients listed in Antrim, Basildon, Colchester and Truro were quite small, which may explain why all blood groups were not represented in their listed patients.

\section{Calculated HLA antibody reaction frequency $(c R F)$ and match grade}

Table 4.8 shows that $43 \%$ of all patients listed for kidney transplantation on the 1st January 2011 were sensitised (cRF 10). Patients on haemodialysis had the largest proportion of sensitised patients with $49 \%$ having a cRF 10 , whilst only $29 \%$ of patients listed pre-emptively were sensitised. This is likely a reflection of haemodialysis patients having an increased risk of exposure to sensitising events (e.g. blood transfusions) relating to dialysis complications and access procedures as compared to those listed pre-emptively and also selective enrichment of the HD population with patients with previous failed transplants (due to longer RRT vintage). Similar reasons are also likely to account for the disparity seen in distribution of highly sensitised patients (cRF 85) which constitute nearly a quarter (23\%) of all patients listed for transplantation. Patients listed on haemodialysis had the largest proportion of highly sensitised patients with $30 \%$ having a cRF 85 , whilst only $8 \%$ of patients listed pre-emptively were highly sensitised.

Centre analysis highlighted wide variation in the proportion of highly sensitised patients listed (table 4.10, figure 4.7) ranging from $50 \%$ of patients or more in Ipswich and Liverpool Aintree, to only $9 \%$ in Wolverhampton.

Similar trends were also noted when analysing match scores by modality (table 4.8 ) with those listed on haemodialysis having the greatest proportion of patients that were difficult to match (33\%) as compared to those who were pre-emptively listed (15\%). Centre variation was also seen in the proportion of patients that were difficult to match ranging from $48 \%$ of patients at London Royal Free, to only $13 \%$ at Wolverhampton (table 4.10, figure 4.8). 
Table 4.9. Number and percentage of prevalent listed patients in each blood group by centre on $01 / 01 / 2011$

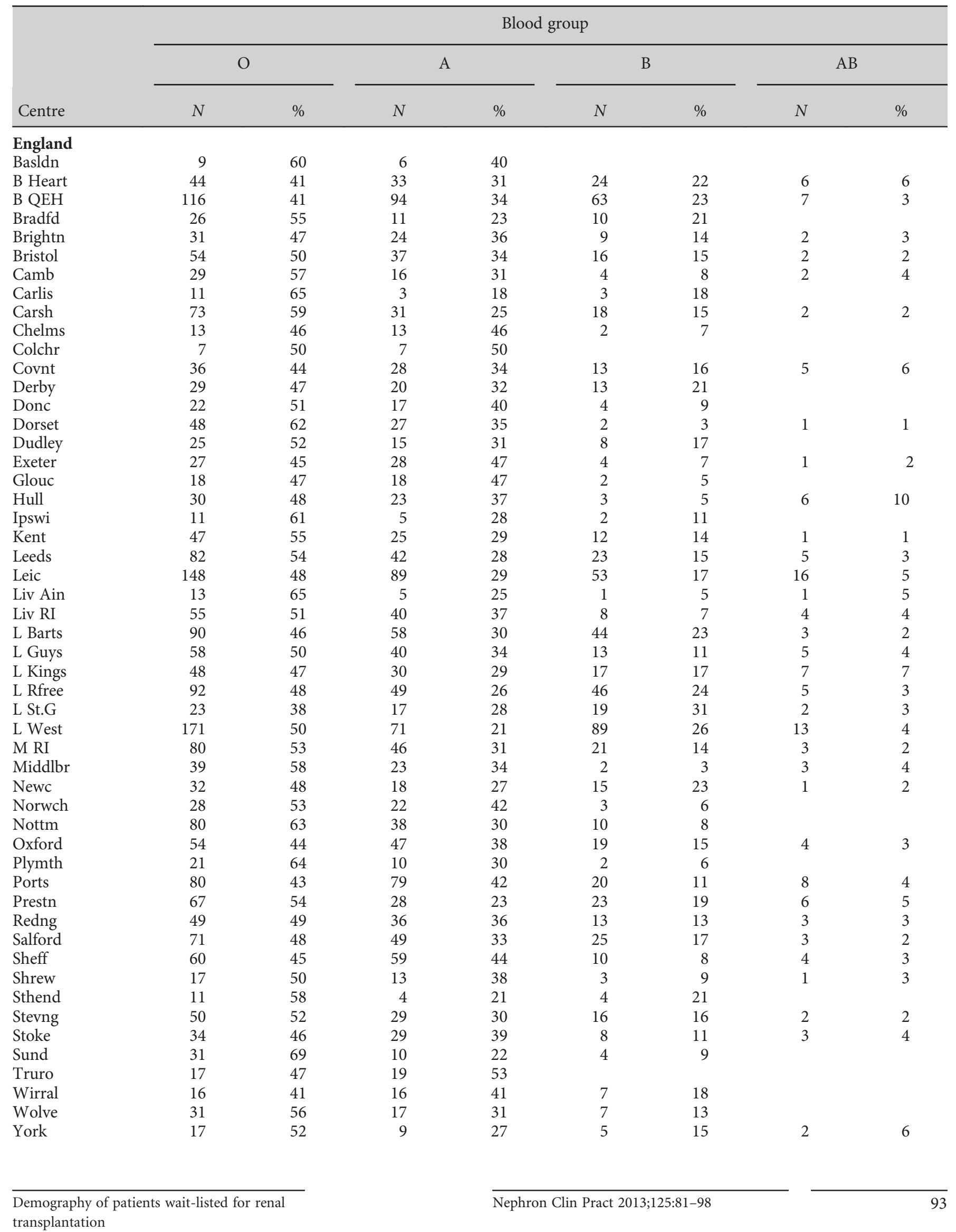


Table 4.9. Continued

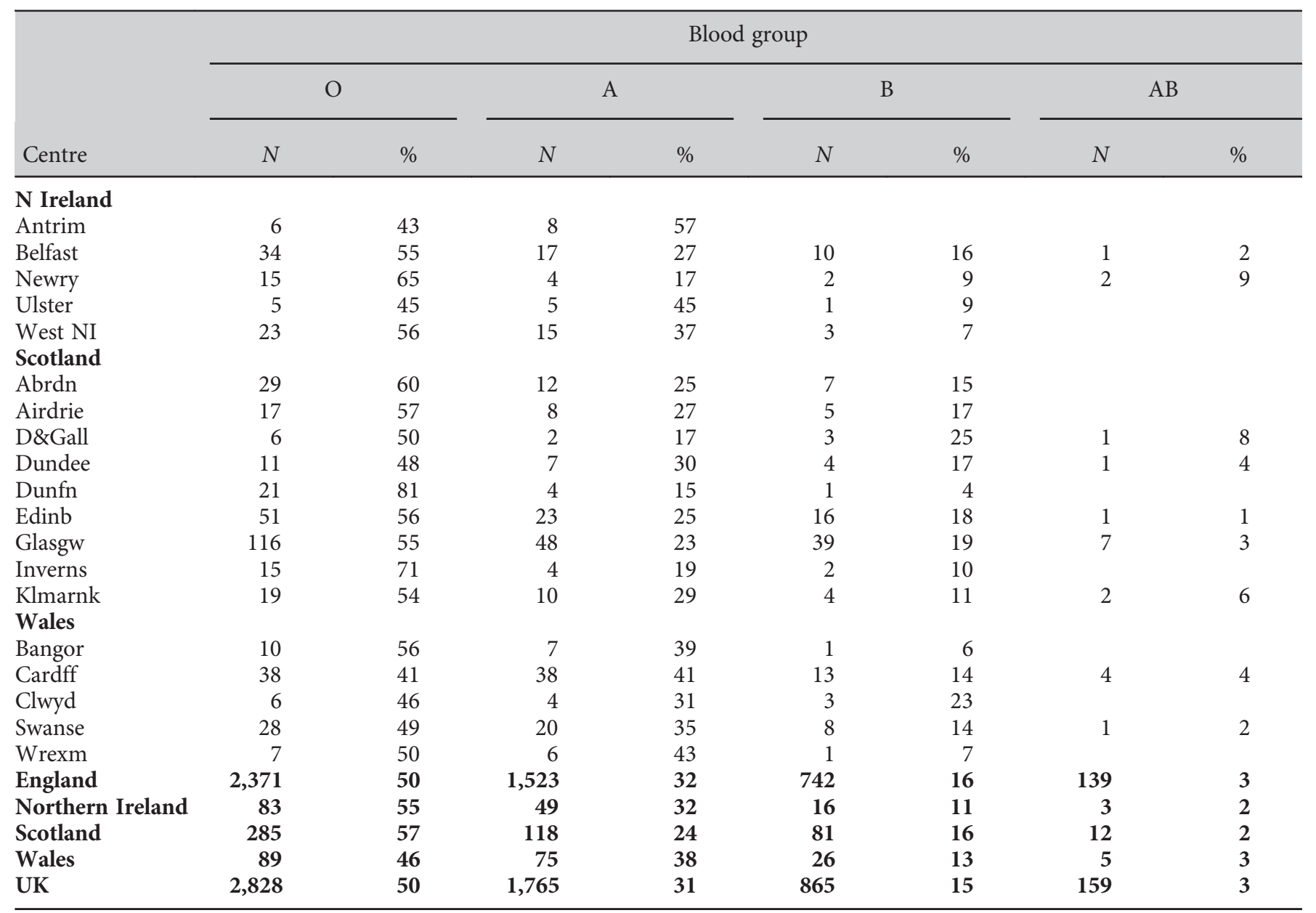

Blank cells denote no patients listed for that blood group within corresponding centre

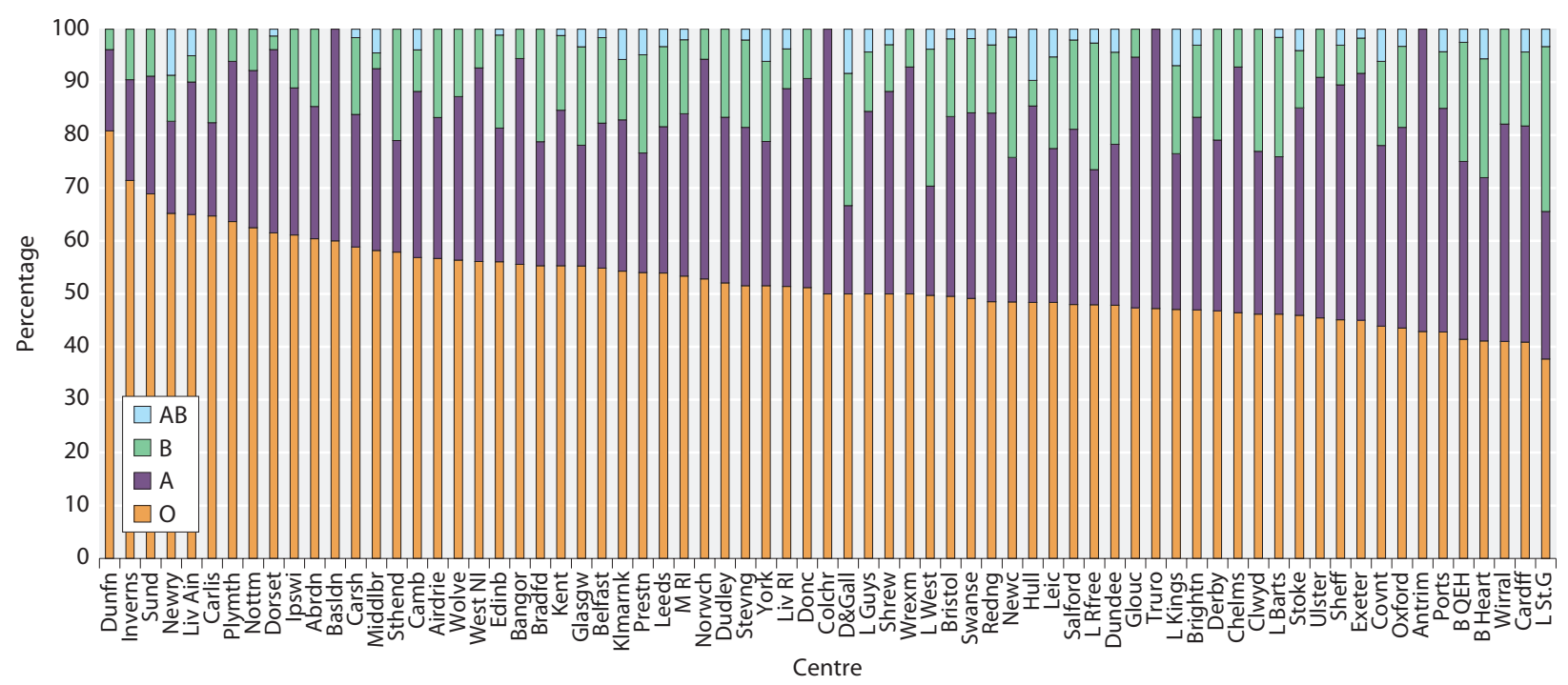

Fig. 4.6. Percentage of listed patients by blood group on $01 / 01 / 2011$ by centre 
Table 4.10. Centre analysis of number and percentage of prevalent listed patients by cRF and match score on $01 / 01 / 2011$

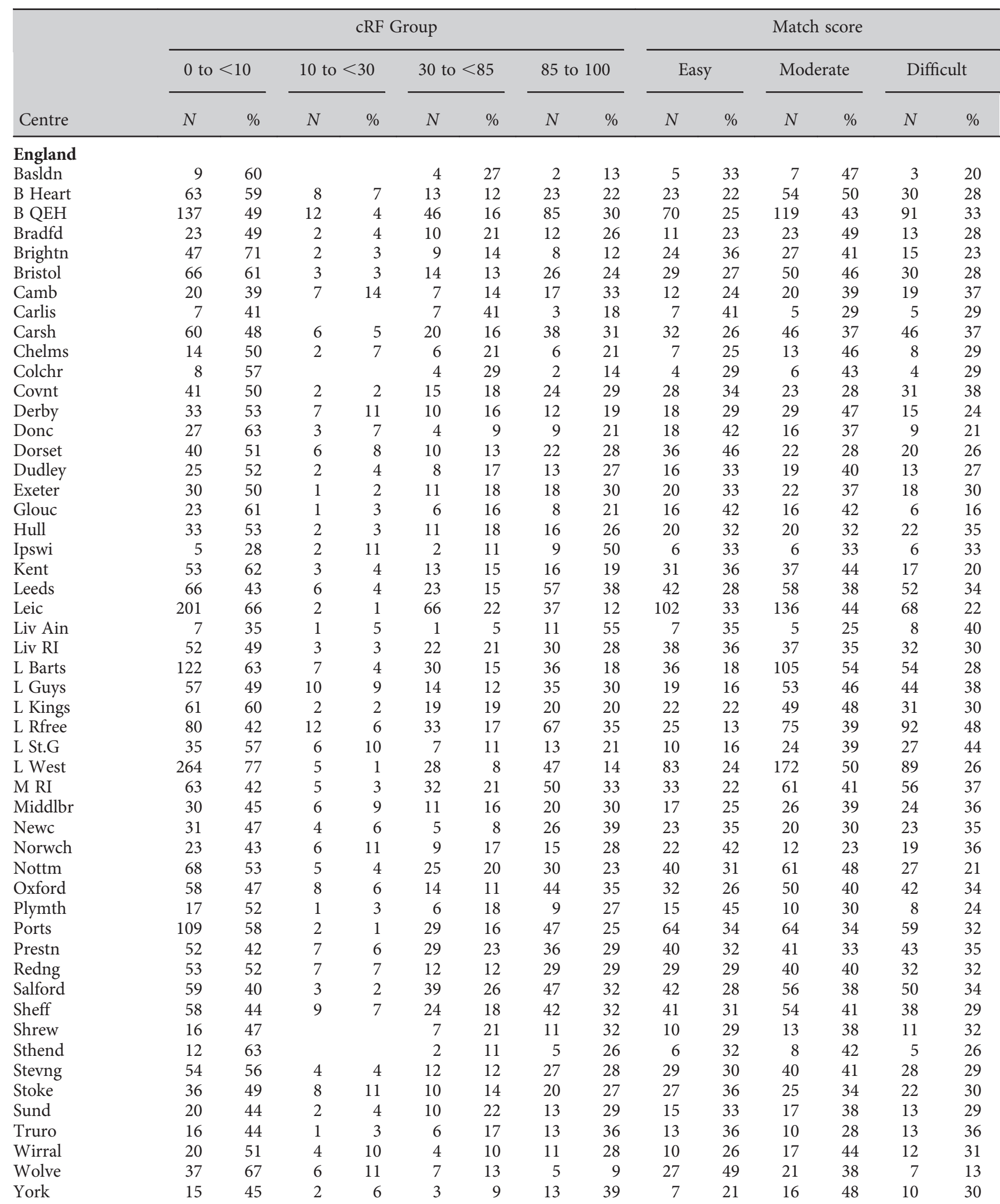


Table 4.10. Continued

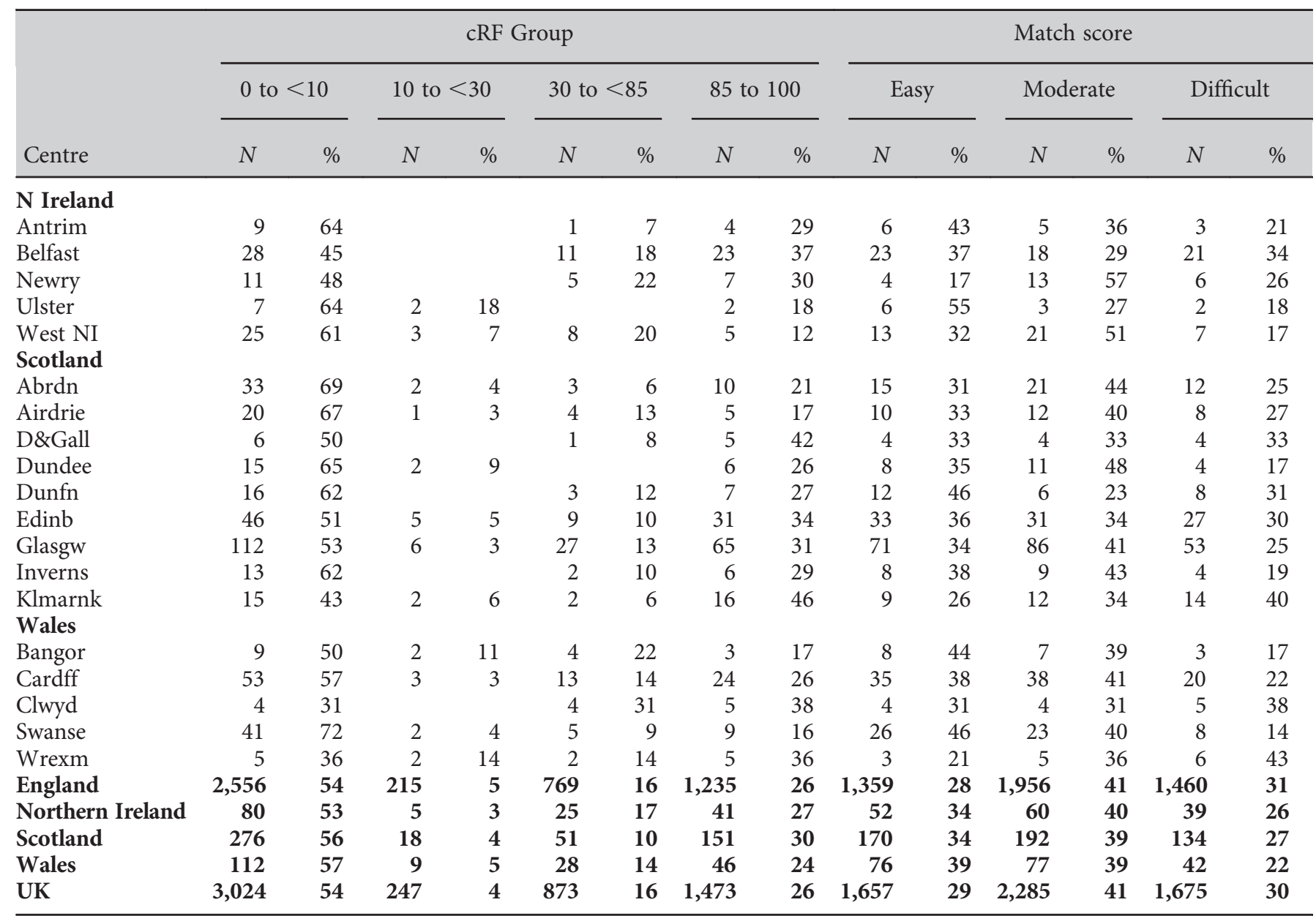

Blank cells denote no patients listed for that category within corresponding centre

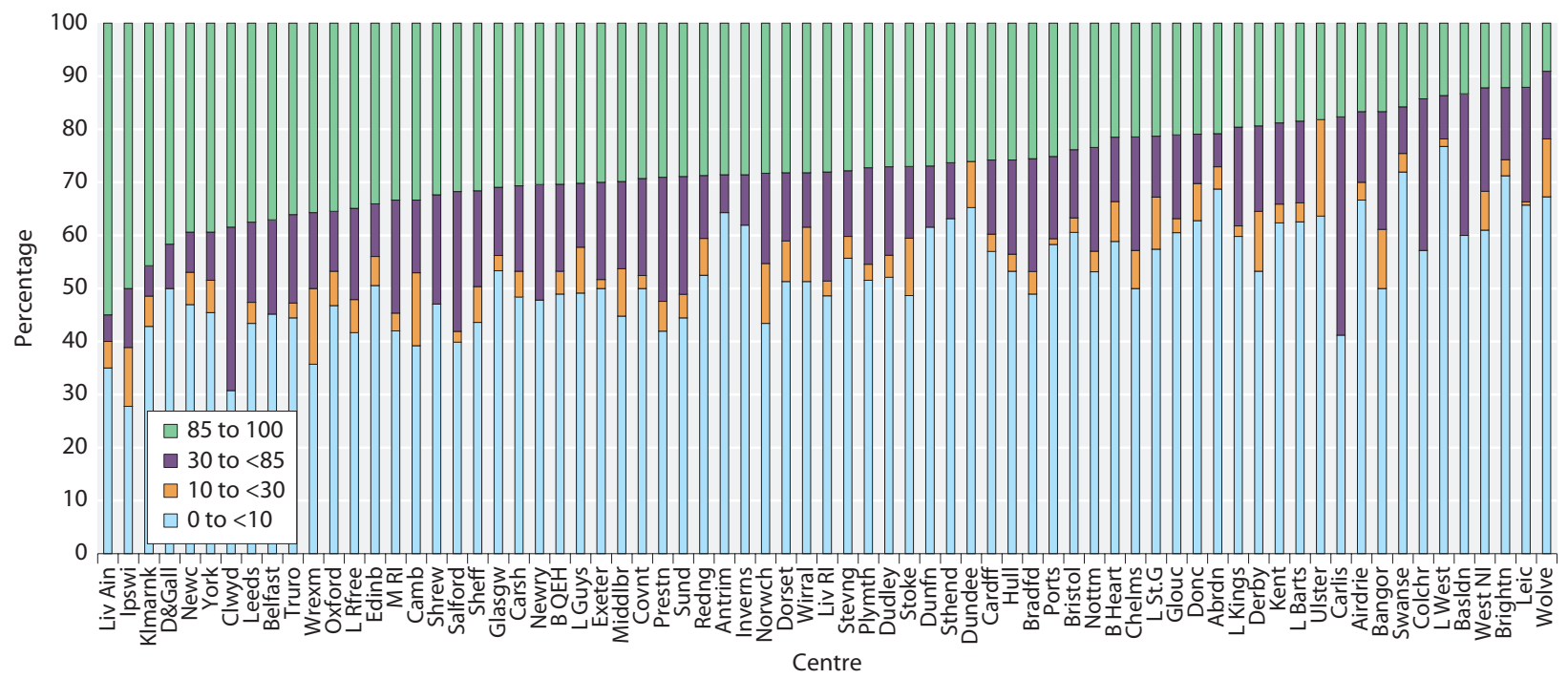

Fig. 4.7. Centre analysis of the percentage of patients listed by calculated reaction frequency group (cRF) on $01 / 01 / 2011$

96

Nephron Clin Pract 2013;125:81-98
Pruthi/Hilton/Pankhurst/Mamode/ Hudson,Roderick/Ravanan 


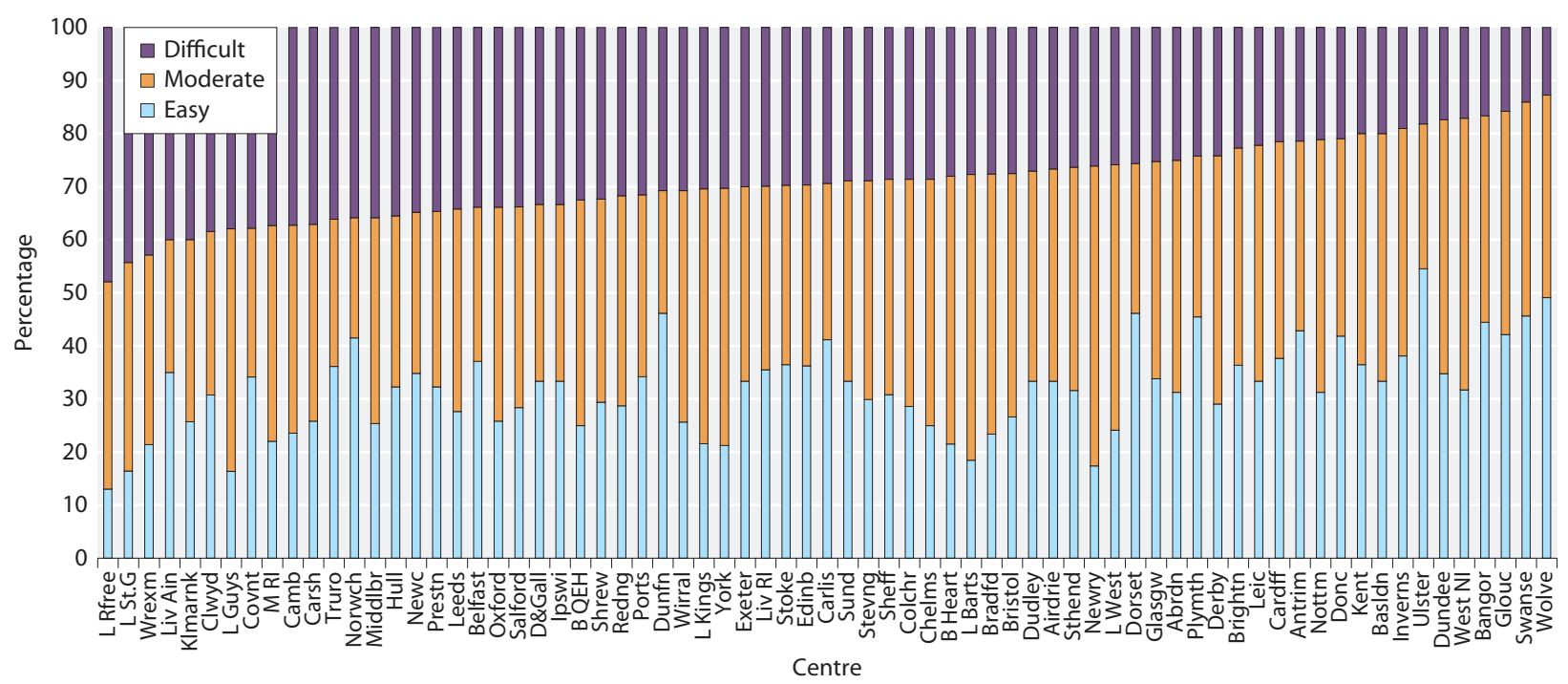

Fig. 4.8. Centre analysis of the percentage of patients listed by match score on $01 / 01 / 2011$

\section{Median waiting times}

The median waiting times for receiving a deceased DBD kidney via the national allocation scheme are shown by ethnicity, blood group and cRF in tables 4.11 , 4.12 and 4.13 respectively. These times were calculated using patients registered for kidney only transplants in the UK between 1st January 2006 and 31st December 2009. The overall median waiting time was 1,160 days for an adult (aged 18 years at time of registration) and 339 days for a paediatric patient (aged $<18$ years at time of registration). Due to the allocation algorithm stratifying patients on level of sensitisation and the need to

Table 4.11. Median waiting time to kidney only transplant in the UK by ethnicity, for patients registered 1st January 2006 to 31st December 2009

\begin{tabular}{|c|c|c|c|}
\hline \multirow[b]{2}{*}{ Ethnicity } & \multirow{2}{*}{$\begin{array}{c}\text { Patients } \\
\text { registered } \\
N\end{array}$} & \multicolumn{2}{|c|}{ Waiting time (days) } \\
\hline & & Median & $95 \% \mathrm{CI}$ \\
\hline \multicolumn{4}{|l|}{ Adult } \\
\hline White & 6,899 & 1,098 & $(1,071-1,125)$ \\
\hline South Asian & 1,252 & 1,411 & $(1,334-1,488)$ \\
\hline Black & 667 & 1,396 & $(1,301-1,491)$ \\
\hline Other & 236 & 1,209 & $(1,046-1,372)$ \\
\hline Total & 9,054 & 1,160 & $(1,136-1,184)$ \\
\hline \multicolumn{4}{|l|}{ Paediatric } \\
\hline White & 248 & 266 & $(212-320)$ \\
\hline South Asian & 73 & 542 & $(458-626)$ \\
\hline Black & 18 & 623 & $(361-885)$ \\
\hline Other & 11 & 276 & $(33-519)$ \\
\hline Total & 350 & 339 & $(263-415)$ \\
\hline
\end{tabular}

Demography of patients wait-listed for renal transplantation match donor and recipient blood groups waiting times are seen to differ across ethnicity, blood groups and level of sensitisation. Adult White patients were seen to have significantly shorter waiting times (1,098 days, CI: $1,071-1,125)$ as compared to Black patients (1,396 days, CI: $1,301-1,491)$ or Asian patients (1,411 days, CI: $1,334-1,488)$ with similar trends seen across paediatric ethnic groups (table 4.11).

Across blood groups, adult patients with blood group $\mathrm{O}$ ( 1,373 days) and $B$ ( 1,343 days) were seen to have significantly longer waiting times than those with blood group A (931 days) or $\mathrm{AB}$ (607 days). These differences were not seen to be significant across paediatric patients (table 4.12).

Table 4.12. Median waiting time to kidney only transplant in the UK by blood group, for patients registered 1st January 2006 to 31st December 2009

\begin{tabular}{|c|c|c|c|}
\hline \multirow[b]{2}{*}{ Blood group } & \multirow{2}{*}{$\begin{array}{l}\text { Patients } \\
\text { registered } \\
N\end{array}$} & \multicolumn{2}{|c|}{ Waiting time (days) } \\
\hline & & Median & $95 \% \mathrm{CI}$ \\
\hline \multicolumn{4}{|l|}{ Adult } \\
\hline $\mathrm{O}$ & 4,066 & 1,373 & $(1,335-1,411)$ \\
\hline $\mathrm{A}$ & 3,364 & 931 & $(899-963)$ \\
\hline $\mathrm{B}$ & 1,259 & 1,343 & $(1,287-1,399)$ \\
\hline $\mathrm{AB}$ & 365 & 607 & $(521-693)$ \\
\hline Total & 9,054 & 1,160 & $(1,136-1,184)$ \\
\hline \multicolumn{4}{|l|}{ Paediatric } \\
\hline $\mathrm{O}$ & 168 & 410 & $(294-526)$ \\
\hline A & 121 & 269 & $(161-377)$ \\
\hline $\mathrm{B}$ & 48 & 241 & $(128-354)$ \\
\hline $\mathrm{AB}$ & 13 & 504 & $(0-1,101)$ \\
\hline Total & 350 & 339 & $(263-415)$ \\
\hline
\end{tabular}

Nephron Clin Pract 2013;125:81-98 
Table 4.13. Median waiting time to kidney only transplant in the UK by sensitisation at registration, for patients registered 1st January 2006 to 31st December 2009

\begin{tabular}{|c|c|c|c|}
\hline \multirow{2}{*}{$\begin{array}{l}\text { Level of } \\
\text { sensitisation }\end{array}$} & \multirow{2}{*}{$\begin{array}{l}\text { Patients } \\
\text { registered } \\
\quad N\end{array}$} & \multicolumn{2}{|c|}{ Waiting time (days) } \\
\hline & & Median & $95 \% \mathrm{CI}$ \\
\hline \multicolumn{4}{|l|}{ Adult } \\
\hline $0-9$ & 6,731 & 1,063 & $(1,039-1,087)$ \\
\hline $10-29$ & 308 & 1,148 & $(1,014-1,282)$ \\
\hline $30-84$ & 1,297 & 1,475 & $(1,400-1,550)$ \\
\hline $85+$ & 718 & 2,218 & $(1,958-2,478)$ \\
\hline Total & 9,054 & 1,160 & $(1,136-1,184)$ \\
\hline \multicolumn{4}{|l|}{ Paediatric } \\
\hline $0-9$ & 217 & 299 & $(212-386)$ \\
\hline $10-29$ & 15 & 138 & $(2-274)$ \\
\hline $30-84$ & 91 & 312 & $(215-409)$ \\
\hline $85+$ & 27 & 1,241 & $(836-1,646)$ \\
\hline Total & 350 & 339 & $(263-415)$ \\
\hline
\end{tabular}

Table 4.13 shows that the level of sensitisation also has an impact on median waiting times with waiting times in highly sensitised patients (2,218 days CI: $1,958-2,478)$ being more than twice that seen in patients who were not sensitised (1,063 days CI: 1,039-1,087), which was highly significant $\mathrm{p} 0.0001$. This trend was also seen in paediatric listed patients with highly sensitised paediatric patients having a significantly longer median waiting time of 1,241 days as compared to 299 days in paediatric patients who were not sensitised.

\section{Summary}

Inter-centre variation exists in the number of patients wait-listed (both pre-emptively and after commencing dialysis) and in the proportion listed across different ethnic groups, age and blood groups. This may reflect differences in geography, local population density, age distribution, ethnic composition, prevalence of diseases predisposing to kidney disease and the social deprivation index of that population as well as individual centre practice patterns. Significant unexplained inter-centre variation was also seen in the proportion of patients listed that were highly sensitised.

Median waiting times are seen to differ significantly across blood groups, degree of sensitisation and ethnic groups, with differences in blood group being one probable factor in explaining the differences in median waiting times seen amongst the major ethnic groups.

Conflicts of interest: none

\section{References}

1 Renal Association Clinical Practice Guidelines Committee: Assessment of the Potential Kidney Transplant Recipient, 5th Edition. 2011. http://www. renal.org/Clinical/GuidelinesSection/AssessmentforRenalTransplantation. aspx

2 UK Kidney Transplantation: organ allocation policy. http://www.odt.nhs. uk/pdf/kidney_allocation_policy.pdf

$3 \mathrm{http} / / /$ www.odt.nhs.uk/pdf/kidney_allocation_policy.pdf

4 Office for National Statistics. www.statistics.gov.uk

5 National Records of Scotland. http://www.nrscotland.gov.uk/

6 Northern Ireland Statistics and Research Agency. http://www.nisra.gov. uk/ 